DOI: $10.5277 /$ epe 160106

\title{
ELEMENTAL COMPOSITION AND ROUGH SOURCE APPORTIONMENT OF FINE PARTICULATE MATTER IN AIR IN CRACOW, POLAND
}

\begin{abstract}
Samples of PM2.5 fraction (particles with aerodynamic diameter $\leq 2.5 \mu \mathrm{m}$ ) of air particulates were collected in winter 2011 and summer 2012 in Cracow, Poland. The concentrations of PM2.5 were $50 \pm 23 \mu \mathrm{g} / \mathrm{m}^{3}$ (wintertime) and $16 \pm 6 \mu \mathrm{g} / \mathrm{m}^{3}$ (summertime). The energy dispersive X-Ray fluorescence method was used for the determination of the concentrations of PM2.5-related elements. Principal component analysis and multilinear regression analysis were used to determine source contributions to ambient concentrations of PM2.5. In wintertime, the sources of air pollution were identified as municipal emission, steel and ferrous industry $(49.2 \%)$, traffic $(37.8 \%)$ and other, not identified sources $(13 \%)$, whereas during summer, they were traffic (53\%), steel and ferrous industry (18\%), and not identified sources $(29 \%)$.
\end{abstract}

\section{INTRODUCTION}

Air particulate matter (PM) has a significant influence on the quality of air. European Union Directives control air pollution due to gases as well as pollution associated with particulate matter [1-3]. Initially, these regulations specified the concentrations of the PM10 fraction (particles with aerodynamic diameter $\leq 10 \mu \mathrm{m}$ ) and those of some selected elements such as $\mathrm{Ni}, \mathrm{As}, \mathrm{Cd}$ and $\mathrm{Pb}$. The concentrations of these elements should not exceed the annual standards of $20,6,5$, and $500 \mathrm{ng} / \mathrm{m}^{3}$. The directives were later extended to include the PM2.5 fraction. PM10 has been the most frequently studied fraction from the perspective of several physicochemical aspects [4-6]. Currently an increasing amount of research is conducted focusing on the characterization of the PM2.5 fraction [7, 8]. Pollution caused by air particulate matter has a detrimental influence on human health. Factors such as PM concentrations, particle sizes and chemical

${ }^{1}$ Faculty of Physics and Applied Computer Science, AGH University of Science and Technology, al. Mickiewicza 30, 30-059 Cracow, Poland, corresponding author L. Samek, e-mail: Lucyna.Samek@ fis.agh.edu.pl 
compositions determine the extent of the negative effect of PM on human health. In particular, small particles can easily penetrate the respiratory tract of a human body and reach blood vessels during the gas exchange. Air particulate matter can also be deposited in people's respiratory track, which may result in severe illnesses such as asthma or heart diseases [9]. The effects on human health are related to both chemical and physical properties of particulate matter. The chemical content of particulate matter has a significant effect on its toxicity [10]. The application of various statistical methods to the elemental content data of PM allowed the identification of its sources. The elements present in PM serve as the tracers of pollution sources in relevant research [6]. Particular sources emit particles whose chemical profiles are more or less established. Traffic related elements can come from exhaust emissions $(\mathrm{Cu}, \mathrm{Zn}, \mathrm{Fe}, \mathrm{Pb}, \mathrm{Br})$, and non-exhaust emissions, examples of which are the wearing out of brakes $(\mathrm{Cu})$ or tires $(\mathrm{Zn})$ and dust resuspended by traffic ( $\mathrm{Fe}, \mathrm{Mn}, \mathrm{Si}, \mathrm{Ca}, \mathrm{Na}, \mathrm{Mg}, \mathrm{Al}$ and $\mathrm{K}$ ) $[8,11,12]$. The indicators of oil combustion are $\mathrm{V}$ and $\mathrm{Ni}$ [8]. Soil particles contain $\mathrm{Al}, \mathrm{Si}, \mathrm{Ca}, \mathrm{Ti}, \mathrm{Fe}, \mathrm{K}$ and many other trace elements. Unfortunately, these elements are also typical indicators of fly ash from coal combustion [8]. The municipal emission sources are characterized by $\mathrm{Cl}, \mathrm{S}$, $\mathrm{Fe}, \mathrm{Br}$ and $\mathrm{Zn}[8,13]$. The ferrous metal source is mainly loaded with $\mathrm{Fe}, \mathrm{Mn}$ and $\mathrm{Zn}$ [14]. The presence of K can indicate either municipal emissions or wood combustion [8]. Cracow is located in the Vistula Valley in Southern Poland. As far as Southern Poland is concerned, according to the report of the Environmental Protection Agency [15], the highest PM2.5 concentrations are observed in Cracow. The main industrial area is located in the eastern part of the city including ferrous and steel, cement, building and ceramics industries as well as a heat and power plant. The location of the city, in a valley, together with special climatic conditions and the narrowness of the streets highly influence the observed level of air pollution. Frequent temperature inversions and low wind speeds are characteristic of the region. The EPA solely controls the level of PM2.5 concentrations in Cracow. The knowledge of elemental composition of PM2.5 is insufficient to successfully evaluate the possible sources and origins of pollution and their contribution to PM2.5. Samek [6] performed a study focusing on PM10 in Cracow. In this work, seasonal variations of PM2.5 concentrations and elemental concentrations of the PM2.5 collected in the city of Cracow, Poland were determined. Moreover, source identification and source apportionment for the PM2.5 fraction were performed. Statistical analyses, principal component analysis (PCA), and multilinear regression analysis (MLRA), were used for the purpose of source identification and apportionment. The results obtained for two seasons were compared.

\section{EXPERIMENTAL}

Sampling. The site selected for the experiment was an urban background area in Cracow [2]. It was located in the district of Krowodrza in the Western part of the city (Cracow, $50^{\circ} 04^{\prime} 01^{\prime \prime} \mathrm{N}, 19^{\circ} 54^{\prime} 47^{\prime \prime} \mathrm{E}$ ), in a build-up area in the vicinity of a park. 
PM concentrations at the site are representative of the concentrations in the residential area of the city. The main local source of pollution is municipal emission, industry and traffic. Traffic density in the city is very high with frequent traffic jams. Factories are located at the distance of about $10 \mathrm{~km}$ from the sampling site. There is also a power plant in the southern area of the city. The Upper Silesian industry area can be found approximately $80 \mathrm{~km}$ to the west from Cracow. Moreover, the zinc industry is situated about $50 \mathrm{~km}$ to the north of the city. 24-hour PM2.5 fraction samples were collected from February 1st to 28th 2011 and from July 16th to August 6th 2012 with the use of a low volume LVS-3 sampler with a flow rate of $2.3 \mathrm{~m}^{3} / \mathrm{h}$. Teflon PTFE ( $46.2 \mathrm{~mm}, 2 \mu \mathrm{m}$ for PM2.5) filters were used as a support. A total of 45 samples were collected during the two seasons of winter 2011 and summer 2012.

Table 1

Measured and certified contents

of elements in NIST SRM2783

\begin{tabular}{|c|c|c|}
\hline Element & $\begin{array}{c}\text { Measured values } \\
{[\mathrm{ng}]}\end{array}$ & $\begin{array}{c}\text { Certified values } \\
{[\mathrm{ng}]}\end{array}$ \\
\hline $\mathrm{K}$ & $2968 \pm 3865$ & $5280 \pm 520$ \\
\hline $\mathrm{Ca}$ & $16305 \pm 3137$ & $13200 \pm 1700$ \\
\hline $\mathrm{Ti}$ & $1394 \pm 189$ & $1490 \pm 240$ \\
\hline $\mathrm{Cr}$ & $129 \pm 70$ & $135 \pm 25$ \\
\hline $\mathrm{Mn}$ & $309 \pm 60$ & $320 \pm 12$ \\
\hline $\mathrm{Fe}$ & $26653 \pm 1086$ & $26500 \pm 1600$ \\
\hline $\mathrm{Cu}$ & $388 \pm 30$ & $404 \pm 42$ \\
\hline $\mathrm{Zn}$ & $2032 \pm 100$ & $1790 \pm 130$ \\
\hline $\mathrm{Pb}$ & $279 \pm 20$ & $317 \pm 54$ \\
\hline
\end{tabular}

Chemical analyses. Filters were weighed on a micro-balance (A and D Instruments HM-202-EC, accuracy $0.01 \mathrm{mg}$ ) in an air conditioned weighing room (temperature $20 \pm 1{ }^{\circ} \mathrm{C}, \mathrm{RH} 50 \pm 5 \%$ ) to evaluate the mass of the PM2.5 fraction following procedures outlined in literature $[16,17]$. Filter weight before and after sampling was recorded and the average of three separate measurements was reported. PM2.5 concentrations were calculated using the values of masses of collected dust and volumes of air that passed through the sampler. The substrates were conditioned for $48 \mathrm{~h}$ in a weighing room before and after sampling. Concentrations of the following elements were determined: $\mathrm{K}, \mathrm{Ca}, \mathrm{Cr}, \mathrm{Mn}, \mathrm{Fe}, \mathrm{Cu}, \mathrm{Zn}, \mathrm{Br}, \mathrm{Sr}$ and $\mathrm{Pb}$. Samples of PM2.5 were analyzed with the use of a multifunctional energy dispersive $\mathrm{X}$-ray fluorescence spectrometer as thin samples. The instrument is a micro-beam X-ray fluorescence spectrometer with capillary $\mathrm{X}$-ray optics, a broad X-ray beam from Mo secondary target for XRF analysis of bulk samples and a total reflection X-ray technique. The Mo tube is the source of X-rays. The tube has the power of $2 \mathrm{~kW}$. The excited $\mathrm{X}$-rays were detected by a $\mathrm{Si}(\mathrm{Li})$ detector 
with a resolution of $170 \mathrm{eV}$ at the energy of $5.9 \mathrm{keV}$. Data collection was completed using the Canberra system. The measurements were carried out under the following conditions: voltage of $55 \mathrm{kV}$, current of $30 \mathrm{~mA}$, measuring time of $10000 \mathrm{~s}$ and under atmospheric air. In order to calculate the concentrations of the elements in the filters, the spectrometer was calibrated using thin-film standards (Micromatter, USA). The calibration was verified by the analysis of the NIST standard reference material 2783 (Table 1). The recovery values at a level of $50 \%$ of the certified value for $\mathrm{K}$ were obtained. The results did not negatively influence further analysis. A proficiency exercise was carried out and it was confirmed that the results obtained for all of the elements were very accurate. This exercise involved the analysis of the collected samples performed by 16 different countries. The XRF spectra were quantitatively analyzed with the use of the QXAS package [18].

Air mass back trajectories. Backward trajectories, ending in Cracow on February 1st, 4th, 6th, 10th, 12th, 24th and 25th 2011 and July 19th, 25th, August 2nd, 4th 2012 at the heights of $1000 \mathrm{~m}, 150 \mathrm{~m}$ and $50 \mathrm{~m}$ were calculated based on the HYSPLIT model [19].

Statistical analyses. Factor analysis (FA), (STATISTICA software) of the elemental concentration data was used to accurately identify the PM2.5 emission sources. MLRA was performed to evaluate the contribution of each source group to the PM2.5 concentration. PCA was completed according to the method described elsewhere [20]. The orthogonal transformation method with Varimax rotation and retention of principal components whose eigenvalues are greater than unit values was utilized. Factor loadings indicated correlations between pollutant species and PM2.5 components and were compared to the composition of emission sources. Absolute zero values were calculated and applied to give absolute FA scores, which were used to perform further studies on the regression of mass to apportion of the PM2.5 to source categories.

\section{RESULTS AND DISCUSSION}

Concentrations of PM2.5 fractions during two different seasons are shown in Fig. 1. The data is accompanied by measurements of temperature during the sampling days. The observed values of PM2.5 concentrations were higher in winter than in summer. The maximum value was reported on February 1st $2011\left(104 \mu \mathrm{g} / \mathrm{m}^{3}\right)$ and the minimum value was noted on February 6th $2011\left(7 \mu \mathrm{g} / \mathrm{m}^{3}\right)$. The mean values were equal to $50 \mu \mathrm{g} / \mathrm{m}^{3}$ and $16 \mu \mathrm{g} / \mathrm{m}^{3}$ for winter and summer, respectively. Furthermore, high values were observed on February 10th, 24th, and 25th 2011, and low values were found on February 4th, 5th, 6th, ad 12th 2011.

The highest daily values were observed on July 25th and August 4th; the lowest ones occurred on July 19th and August 2nd. Remoundaki et al. [7] performed research on PM2.5 fractions in Athens and obtained a mean value of $21 \mu \mathrm{g} / \mathrm{m}^{3}$ for summer and 
$22 \mu \mathrm{g} / \mathrm{m}^{3}$ for winter of 2010 . The results presented in this work showed much higher mean daily values in the winter and a slightly lower number in the summer. Cracow is located in colder climate than Athens. High winter concentrations of PM2.5 in Cracow are most likely due to municipal emission sources. Putaud et al. [21] presented data on PM2.5 annual average concentrations for several cities in Europe and found them to be in the range of $3-35 \mu \mathrm{g} / \mathrm{m}^{3}$. It can be seen that the results obtained during summer were in the range stated by Putaud et al. [21] and those attained during winter exceeded the average annual concentrations. These high values of PM2.5 concentrations may be associated with the fact that combustion due to heating is more common in Cracow than in other European cities.
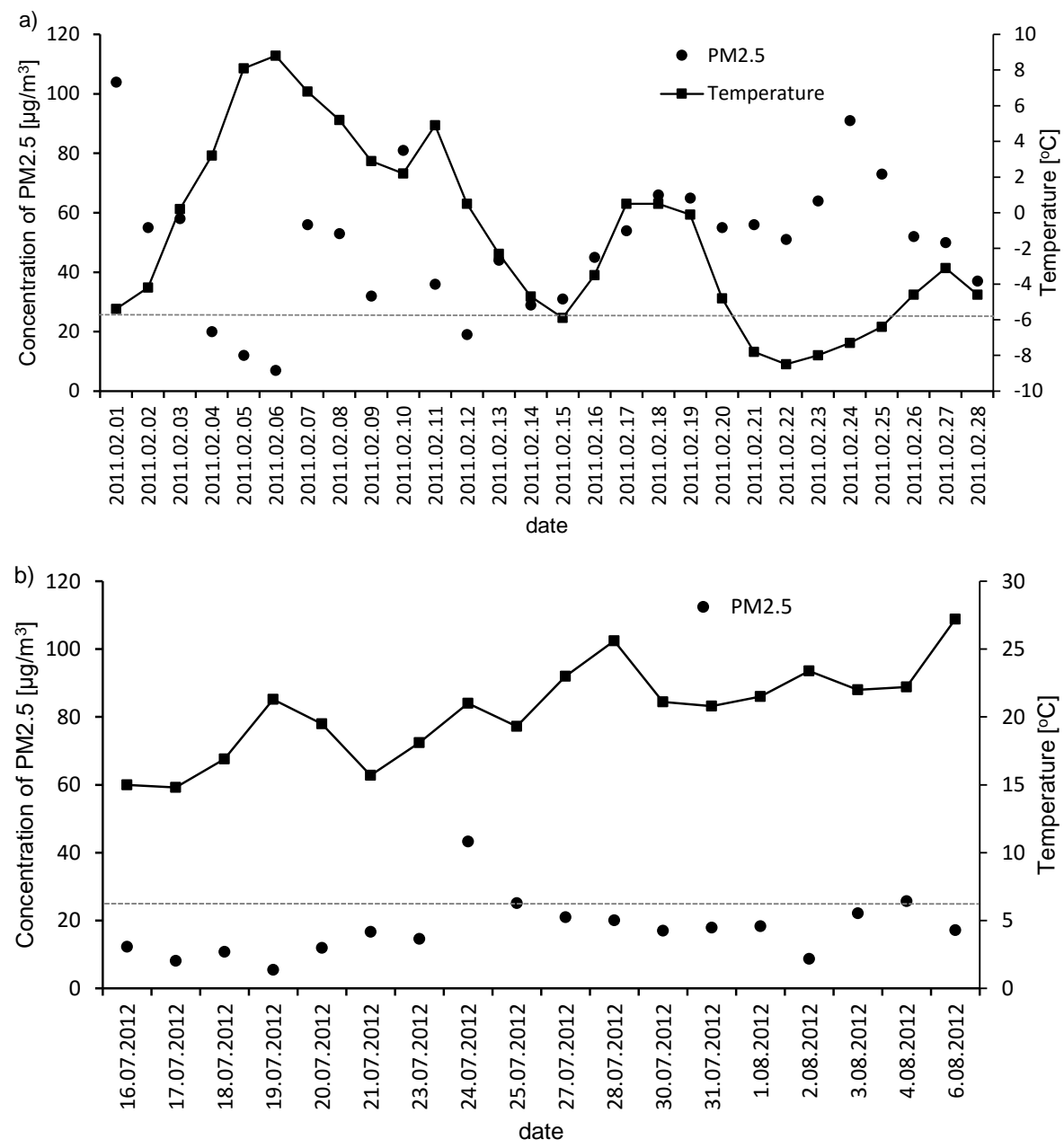

Fig. 1. Concentrations of PM2.5 fraction and ambient temperatures for winter 2011 (a), and summer 2012 (b) 
Concentrations [in $\mu \mathrm{g} / \mathrm{m}^{3}$ ] and elemental concentrations [in $\mathrm{ng} / \mathrm{m}^{3}$ ]

of PM2.5 fraction for winter 2011 and summer 2012

\begin{tabular}{|c|c|c|c|c|c|c|c|}
\hline \multirow[b]{2}{*}{ Component } & \multicolumn{3}{|c|}{ Winter 2011} & \multicolumn{3}{|c|}{ Summer 2012} & \multirow[b]{2}{*}{ LLD } \\
\hline & Minimal & Maximal & $\begin{array}{c}\text { Mean } \\
\pm \text { st. dev. }\end{array}$ & Minimal & Maximal & $\begin{array}{c}\text { Mean } \\
\pm \text { st. dev. }\end{array}$ & \\
\hline PM2.5 & 7 & 104 & $50 \pm 23$ & 5 & 26 & $16 \pm 6$ & \\
\hline $\mathrm{K}$ & 28 & 1571 & $733 \pm 440$ & 60 & 289 & $172 \pm 72$ & 15 \\
\hline $\mathrm{Ca}$ & 31 & 1115 & $357 \pm 278$ & 30 & 796 & $196 \pm 220$ & 7.2 \\
\hline $\mathrm{Cr}$ & $<$ LLD & 13.1 & $7.1 \pm 4.5$ & $<$ LLD & 6.5 & $<$ LLD & 3.0 \\
\hline $\mathrm{Mn}$ & $<\mathrm{LLD}$ & $<$ LLD & $<$ LLD & $<$ LLD & 4.9 & $4.5 \pm 2.9$ & 2.5 \\
\hline $\mathrm{Fe}$ & 6.3 & 798 & $234 \pm 200$ & 50 & 359 & $173 \pm 89$ & 1.0 \\
\hline $\mathrm{Cu}$ & 10 & 32 & $10 \pm 12$ & 2.1 & 8.4 & $5.5 \pm 1.8$ & 0.8 \\
\hline $\mathrm{Zn}$ & 16 & 254 & $116 \pm 62$ & 20 & 102 & $44 \pm 20$ & 0.6 \\
\hline $\mathrm{Br}$ & 5 & 45 & $21 \pm 12$ & 2.6 & 13.8 & $8.9 \pm 3.2$ & 1.0 \\
\hline $\mathrm{Sr}$ & 16 & 29 & $22 \pm 3$ & 1.3 & 7.6 & $3.8 \pm 2$ & 1.0 \\
\hline $\mathrm{Pb}$ & 10 & 99 & $38 \pm 21$ & 6 & 31 & $15 \pm 14$ & 1.2 \\
\hline
\end{tabular}

${ }^{\mathrm{a}}$ st. dev. in the table represents the variability of elemental concentrations in all collected samples. LLD represents the low detection limit. LLD $=3 B^{1 / 2} c / N$, where $B$ - background, $N$ - peak surface area, $c$ - concentration.

The results of elemental analysis of PM2.5 are presented in Table 2. The table contains minimum, maximum and mean values for both seasons as well as low detection limits (LLD) for analyzed elements

Concentrations of the following elements were determined: $\mathrm{K}, \mathrm{Ca}, \mathrm{Cr}, \mathrm{Mn}, \mathrm{Fe}, \mathrm{Cu}, \mathrm{Zn}$, $\mathrm{Br}, \mathrm{Sr}$, and $\mathrm{Pb}$. In wintertime concentrations of potassium varied from 28 to $1572 \mathrm{ng} / \mathrm{m}^{3}$ with a mean value of $733 \mathrm{ng} / \mathrm{m}^{3}$. Between February 3rd and 12th concentrations of potassium were lower than during the rest of the month. This was likely due to the higher ambient temperature and, as a result, less emission coming from heating in residential areas. During the second part of February (13th-28th), lower ambient temperatures were observed (significantly below $0{ }^{\circ} \mathrm{C}$, Fig. 1) and considerably higher concentrations of potassium were noted. The increased concentrations were caused mainly by combustion of coal and wood in local houses. In summertime, concentrations of potassium were significantly lower than in wintertime and varied from 60 to $290 \mathrm{ng} / \mathrm{m}^{3}$ with a mean value of $172 \mathrm{ng} / \mathrm{m}^{3}$. Variability in the results for the summer period was smaller than for those obtained during the wintertime. An exception was reported on the day of July 24th 2012. High concentrations of all analyzed elements were observed. The results were influenced by construction works being performed near the sampling site. Both calcium and iron had higher concentrations in winter (mean values 357 and $254 \mathrm{ng} / \mathrm{m}^{3}$, respectively) than in summer (mean values 196 and $172 \mathrm{ng} / \mathrm{m}^{3}$, respectively). Highest concentrations of $\mathrm{Ca}$ and $\mathrm{Fe}$ were observed on February 21st, 24th and 25th as well as on August 6th. 
Table 3

The directions of air mass inflows coming to Cracow during the days of high and low concentrations of PM2.5 fraction

\begin{tabular}{|c|c|c|c|c|c|}
\hline \multirow[b]{2}{*}{$\begin{array}{l}\text { Sampling } \\
\text { date }\end{array}$} & \multicolumn{3}{|c|}{ Direction of inflows coming } & \multirow{2}{*}{$\begin{array}{c}\text { Concentration } \\
\text { of PM2.5 } \\
{\left[\mu \mathrm{g} / \mathrm{m}^{3}\right]}\end{array}$} & \multirow[b]{2}{*}{$\begin{array}{l}\text { Elements with } \\
\text { high concentration }\end{array}$} \\
\hline & $\begin{array}{c}\text { Height } \\
50 \mathrm{~m}\end{array}$ & $\begin{array}{l}\text { Height } \\
150 \mathrm{~m}\end{array}$ & $\begin{array}{l}\text { Height } \\
1000 \mathrm{~m}\end{array}$ & & \\
\hline 1.02 .2011 & SW & SW & SW & high -104 & $\mathrm{~K}, \mathrm{Zn}, \mathrm{Br}, \mathrm{Pb}$ \\
\hline 4.02 .2011 & $\mathrm{~W}$ & $\mathrm{~W}$ & $\mathrm{~W}$ & low -20 & \\
\hline 5.02 .2011 & $\mathrm{~S}$ & $\mathrm{~S}$ & $\mathrm{~S}$ & low -12 & \\
\hline 6.02 .2011 & $\mathrm{~W}$ & $\mathrm{~W}$ & $\mathrm{~W}$ & low -7 & \\
\hline 10.02 .2011 & NW & NW & NW & high -81 & $\mathrm{Zn}, \mathrm{Br}, \mathrm{Pb}$ \\
\hline 12.02 .2011 & NW & NW & $\mathrm{N}$ & low -19 & \\
\hline 24.02 .2011 & $\mathrm{NE}$ & $\mathrm{NE}$ & $\mathrm{NE}$ & high -91 & $\mathrm{~K}, \mathrm{Ca}, \mathrm{Fe}, \mathrm{Cu}, \mathrm{Zn}$ \\
\hline 25.02 .2011 & $\mathrm{NE}$ & $\mathrm{NE}$ & $\mathrm{NE}$ & high -73 & $\mathrm{~K}, \mathrm{Ca}, \mathrm{Fe}, \mathrm{Cu}, \mathrm{Zn}$ \\
\hline 19.07 .2012 & SW & SW & $\mathrm{W}$ & low -5.5 & \\
\hline 25.07 .2012 & $\mathrm{E}$ & $\mathrm{E}$ & SE & high -25 & $\mathrm{Fe}, \mathrm{Zn}, \mathrm{Br}, \mathrm{Pb}$ \\
\hline 2.08 .2012 & SE & SE & $\mathrm{S}$ & low -9 & $\mathrm{~K}, \mathrm{Fe}, \mathrm{Zn}, \mathrm{Br}$ \\
\hline 4.08 .2012 & NW & NW & $\mathrm{W}$ & high -26 & $\mathrm{~K}, \mathrm{Cr}, \mathrm{Fe}, \mathrm{Zn}, \mathrm{Br}, \mathrm{Pb}$ \\
\hline
\end{tabular}

Concentrations of $\mathrm{Br}$ and $\mathrm{Pb}$ reached their highest values on February 1st and 10th during winter and on July 21st and 24th during summer. The second half of February was characterized by lower concentrations of $\mathrm{Br}$ and $\mathrm{Pb}$ in contrast to the increasing concentrations of $\mathrm{K}, \mathrm{Ca}, \mathrm{Fe}, \mathrm{Cu}$ and $\mathrm{Sr}$. The values reported for copper during wintertime were almost two times higher than the ones recorded during summer. The main sources of copper are expected to be industry and traffic. Zinc concentrations were observed to have the highest values on February 1st, 10th and 24th. The mean value for winter $\left(116 \mathrm{ng} / \mathrm{m}^{3}\right)$ was more than double of that recorded for summer $\left(44 \mathrm{ng} / \mathrm{m}^{3}\right)$. The variability of elemental concentrations in summertime was small while in wintertime it was large. On February 1st inflows of polluted air masses were recorded to be from the South-West direction (Figs. 2, 3) where a heat and power station is located. High concentrations of $\mathrm{K}, \mathrm{Zn}, \mathrm{Br}$ and $\mathrm{Pb}$ were observed on that day (Table 3). On February 10th inflows of polluted air masses were recorded to be from the North-West direction where the $\mathrm{Zn}$ and $\mathrm{Pb}$ industry is located (approximately $50 \mathrm{~km}$ away from Cracow). High concentration of $\mathrm{Zn}, \mathrm{Br}$ and $\mathrm{Pb}$ were observed that day (Table 3). Moreover, on February 24th and 25th inflows of polluted air masses were from the North-East direction (Figs. 2, 3). High elemental concentrations were noted for $\mathrm{K}, \mathrm{Ca}, \mathrm{Fe}, \mathrm{Cu}$, and $\mathrm{Zn}$. These can be related to the steel and ferrous as well as cement industry located in Nowa Huta. Additionally, the increased concentrations of $\mathrm{Cu}$ and $\mathrm{Zn}$ can be attributed to the city traffic. Air masses were flowing from the East direction on July 25th. High concentrations of $\mathrm{Fe}, \mathrm{Zn}, \mathrm{Br}$ and $\mathrm{Pb}$ were observed that day. This can also be associated with the steel and ferrous industry located in Nowa Huta and the city traffic. On August 4th air masses 
were observed to be coming from the North-West direction. During that day high concentrations of $\mathrm{K}, \mathrm{Cr}, \mathrm{Fe}, \mathrm{Zn}, \mathrm{Br}$ and $\mathrm{Pb}$ were found. The increased values can be attributed to the steel industry located in the Silesian region and the $\mathrm{Zn}$ and $\mathrm{Pb}$ industry located at a distance of about $50 \mathrm{~km}$ from Cracow.

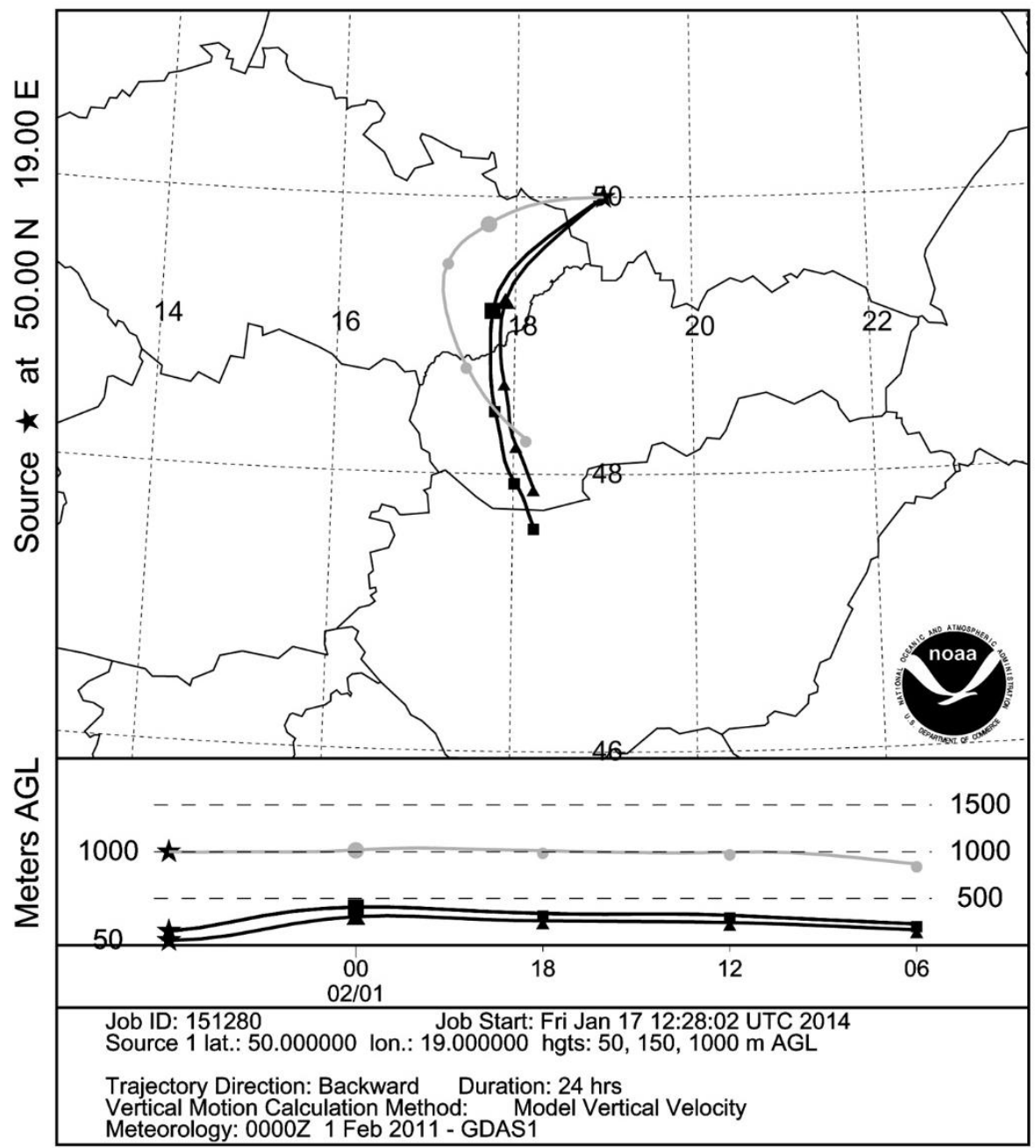

Fig. 2. Backward trajectories ending in Cracow on February 1st, 2011

The results of PCA are shown in Table 4. Two PCA factors were obtained for both seasons. Soil particles are composed of oxides of $\mathrm{Al}, \mathrm{Si}, \mathrm{Ca}, \mathrm{Ti}, \mathrm{Fe}, \mathrm{K}$ with many trace elements. These elements are also typical indicators of fly ash from coal combustion [8]. Resuspension of roadway dust is also dominated by crustal elements: $\mathrm{Si}, \mathrm{Fe}, \mathrm{Ca}, \mathrm{Na}$, $\mathrm{Mg}, \mathrm{Al}$ and $\mathrm{K}$ [12]. Metals related to brake and tire wear, and tailpipe emissions are $\mathrm{Cu}$, 
$\mathrm{Zn}, \mathrm{Pb}, \mathrm{Sb}, \mathrm{Br}$ and $\mathrm{Cd}[11,12]$. The municipal emission sources constitute of $\mathrm{Cl}, \mathrm{S}, \mathrm{Fe}$, $\mathrm{Br}$ and $\mathrm{Zn}[13,20]$. The ferrous metal source is mainly loaded with $\mathrm{Fe}, \mathrm{Mn}$ and $\mathrm{Zn}$ [14]. During wintertime, the tracer elements (the ones with high correlation coefficients) were: $\mathrm{K}, \mathrm{Ca}, \mathrm{Fe}, \mathrm{Cu}, \mathrm{Zn}$ and $\mathrm{Sr}$.

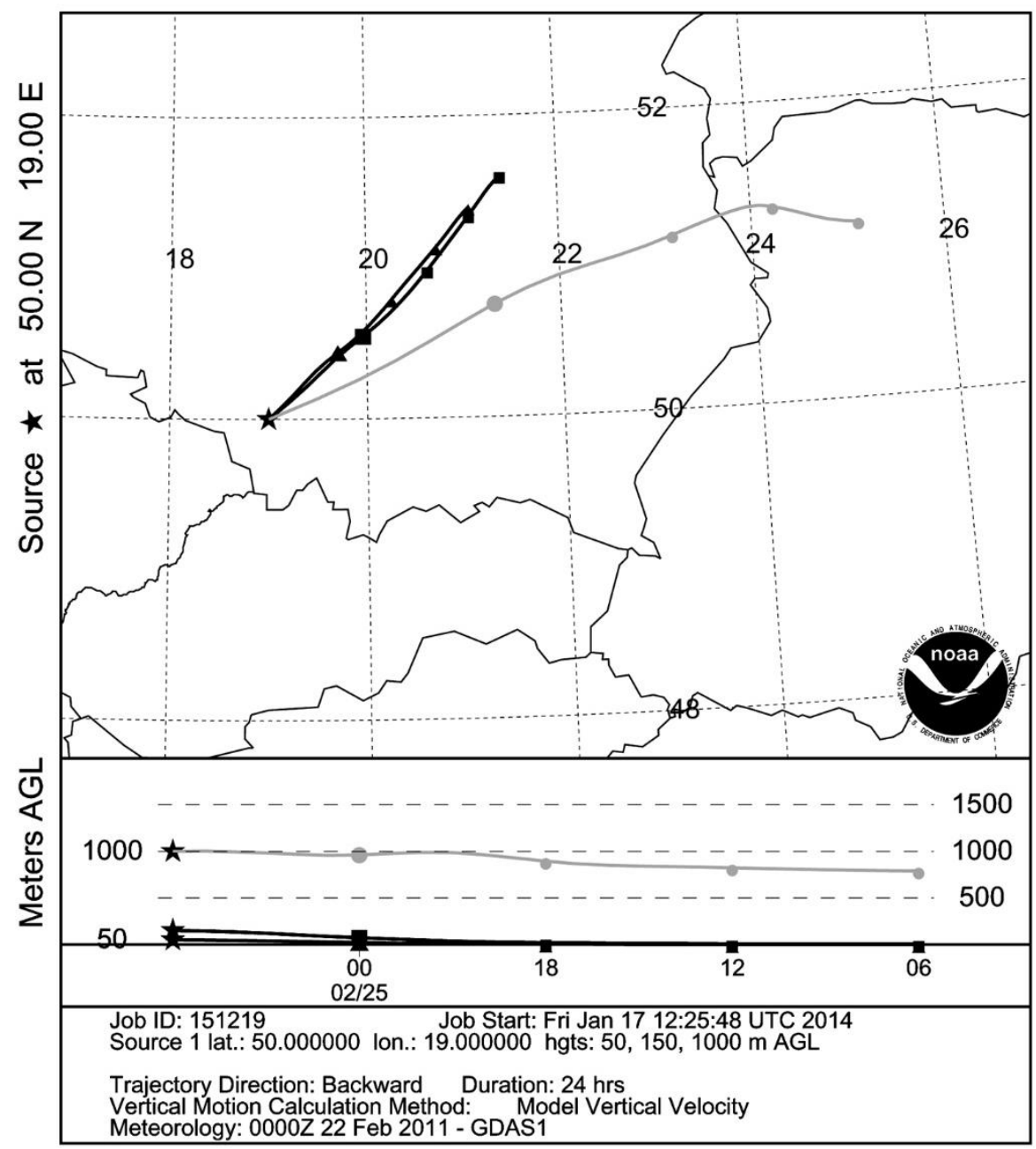

Fig. 3. Backward trajectories ending in Cracow on February 25th, 2011

The main sources of pollution were identified based on the presence of these elements. They could probably be due to municipal emission and industry (factor 1 - winter in Table 4) [8]. Hansen et al. [22] found that wood combustion fly ash contains potassium and calcium. For the factor 2 PCA analysis the tracers were $\mathrm{Br}$ and $\mathrm{Pb}$. The presence of these elements could indicate traffic as a source (factor 2 - winter in Table 4). 
Table 4

Factor loadings of elemental data for winter 2011 and summer 2012

\begin{tabular}{|c|c|c|c|c|}
\hline \multirow{3}{*}{ Elements } & \multicolumn{2}{|l|}{ Winter } & \multicolumn{2}{|c|}{ Summer } \\
\hline & $\begin{array}{l}\text { Municipal emission } \\
\text { /Industry }\end{array}$ & Traffic & Traffic & Industry \\
\hline & Factor 1 & Factor 2 & Factor 1 & Factor 2 \\
\hline $\mathrm{K}$ & 0.94 & 0.19 & 0.59 & 0.51 \\
\hline $\mathrm{Ca}$ & 0.78 & 0.29 & 0.10 & 0.87 \\
\hline $\mathrm{Mn}$ & & & 0.51 & 0.72 \\
\hline $\mathrm{Fe}$ & 0.76 & 0.02 & 0.59 & 0.66 \\
\hline $\mathrm{Cu}$ & 0.69 & 0.56 & 0.75 & 0.47 \\
\hline $\mathrm{Zn}$ & 0.81 & 0.49 & 0.84 & 0.16 \\
\hline $\mathrm{Br}$ & 0.25 & 0.89 & 0.88 & 0.35 \\
\hline $\mathrm{Sr}$ & 0.71 & 0.66 & 0.27 & 0.88 \\
\hline $\mathrm{Pb}$ & 0.09 & 0.96 & 0.90 & 0.07 \\
\hline Variance, $\%$ & 0.49 & 0.35 & 0.43 & 0.34 \\
\hline
\end{tabular}
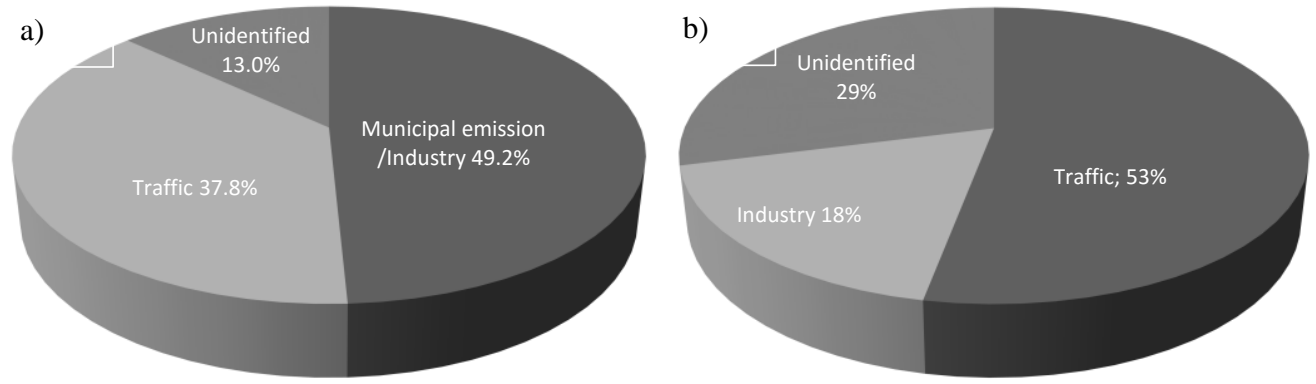

Fig. 4. Percentage mean contribution of sources to total PM2.5 fraction measured in winter (a) and summer (b)

The sources of air pollution for summertime could be identified as traffic as well as industry. Factor 1 could be connected with traffic (factor 1-summer in Table 4). The tracer elements were $\mathrm{Zn}, \mathrm{Br}$ and $\mathrm{Pb}$. The presence of $\mathrm{Zn}$ in particulate matter may be due to the wear product of tire rubber [23]. Factor 2, probably associated with industry, was characterized by $\mathrm{Ca}, \mathrm{Mn}, \mathrm{Fe}$ and $\mathrm{Sr}$ (factor 2-summer in Table 4). These elements indicate cement and steel and ferrous industry. MLRA was performed for each sample and the obtained mean values for winter and summer are presented in Fig. 4a, b. During wintertime municipal emission as well as the industry factor contributed to $49.2 \%$, traffic accounted for $37.8 \%$ and unidentified sources constituted $13 \%$ of the total PM2.5 pollution. It is possible that the unidentified sources could be due to the formation of secondary aerosols. In the second half of February, when air temperatures were below zero degree Celsius, contribution of municipal emission and industry sources were significant (from 69\% to 84\%) whereas from February 1st to 12th, when air temperatures 
were higher, contribution of these sources was much lower (from $2 \%$ to $44 \%$ ). This data confirmed that during the days of lower air temperatures in Cracow air particulate matter pollution was caused mainly by local heating including coal fired furnaces and electrical power plants. In Cracow a lot of people use low quality coal for heating in furnaces at homes. During the relatively warmer days of winter the traffic dominated as a pollution source. In summertime the mean contribution of traffic was equal to $53 \%$ (values varied from $40 \%$ to $60 \%$ ) with the exception of August 6th when it was equal to $15 \%$. On this day, the contribution of industry was reported to be $60 \%$. In summertime, the mean contribution of industry was equal to $18 \%$ (values varied from $5 \%$ to $40 \%$ ). In addition, $29 \%$ of the pollution was attributed to unidentified sources. It was possibly due to high concentrations of sulfates, nitrates and a certain amount of organic carbon which are characteristic of secondary pollutants typically formed in summer when solar radiation and temperatures are high [14].

\section{CONCLUSIONS}

Seasonal variations of PM2.5 and elemental concentrations in the city of Cracow were studied. High concentrations were observed during wintertime. Elemental concentrations were almost two times higher in winter than those in summer. Statistical analyses suggest that municipal emission and industry were the major contributors during wintertime, while traffic was the most significant pollutant in summertime; it was followed by unidentified sources and industry. The increased percentage value of traffic is attributed to the fact that the city is less congested during summer which lowers the amount of pollution in general and results in a more pronounced traffic contribution. PM2.5 contains particles with lower diameter which, as a result, can be easily deposited in the human respiratory system. It is therefore crucial to be aware of the levels of concentration of the PM2.5 fraction and their significance to more efficiently protect the environment and human health.

\section{ACKNOWLEDGEMENTS}

The International Atomic Energy Agency, project number RER/1/008, together with the Polish Ministry of Science and Higher Education and its grants for scientific research partially financed this work. The authors gratefully acknowledge the NOAA Air Resources Laboratory (ARL) for the provision of the HYSPLIT transport and dispersion model and/or READY website (http://www.ready.noaa.gov) used in this publication.

\section{REFERENCES}

[1] Council Directive 1999/30/EC of 22 April 1999. Official Journal of the European Communities 1999, L 163, 41.

[2] Directive 2008/50/EC of the European Parliament and of the Council of 21 May 2008. 
[3] Directive 2004/107/EC of the European Parliament and of the Council of December 2004. Official Journal of the European Union 2004.

[4] Bar M.A., Baumbach G., Sarachage-Ruiz L., Kleanthes S., Identification of PM10 sources in Mediterranean Island, Water, Air, Soil Poll.: Focus, 2009, 9, 39.

[5] Lazaridis M., Dzumbova L., Kopanakis I, Ondracek J., Glytsos T., Aleksandropoulou V., Voulgarakis A., Katsivela E., Mihelopoulos N., Eleftheriadis K., PM10 and PM2.5 levels in the Easten Mediterranean (Akrotiri Research Station, Crete, Greece), Water, Air, Soil Poll., 2008, $199,85$.

[6] SAMEK L., Source apportionment of the PM10 fraction of particulate matter collected in Cracow, Poland, Nukleonika, 2012, 57, 601.

[7] Remoundaki E., Papayannts A., Kassomenos P., Mantas E., Kokkalis P., Tsezos M., Influence of Saharan dust transport events on PM2.5 concentrations and composition over Athens, Water, Air, Soil Poll., 2013, 224, 1.

[8] Vallius M., Janssen N.A., Heinrich J., Hoek G., Runskane J., Cyrys J., Van Grieken R., Sources and elemental composition of ambient PM2.5 in three European cities, Sci. Total Environ., 2005, 337, 147.

[9] Stochel M., Breitner S., Cyrys J., Pitz M., Wolke G., Kreyling W., Heinrich J., Wichmann H.E., Peters A., Daily mortality and particulate matter in different size classes in Erfurt, Germany, J. Exp. Environ. Epid., 2007, 17, 458.

[10] Karanasiou A.A., Sitaras L.E., Siskos P.A., Eleftheriadis K., Size distribution and sources of trace metals and n-alkanes in the Athens urban aerosol during summer, Atmos. Environ., 2007, 41, 2368.

[11] Lammel G., Rohrl A., SchreIBer H., Atmospheric lead and bromine in Germany. Post abatement levels, variabilities and trends, Environ. Sci. Pollut., 2002, 9, 397.

[12] PANT P., HARRISON R.M., Estimation of the contribution of road traffic emissions to particulate matter concentrations from field measurements. A review, Atmos. Environ., 2013, 77, 78.

[13] Chueinta W., Hopke P.K., PAATERo P., Investigation of sources of atmospheric aerosol urban and suburban residential areas in Thailand by positive matrix factorization, Atmos. Environ., 2000, 34, 3319.

[14] Querol X., Viana M., Alastuey A., Amato F., Moreno T., Castillo S., Pey J., De La Rosa J., Sanchez De La Campa A., Artinano B., Salvador P., Garcia Dos Santos S., Fernandez-Patier R., Moreno-Grau S., Negral L., Minguillon M.C., Monfort E., Gil J.I., InZa A., Ortega L.A., Santamaria J.M., ZabalZa J., Source origin of trace elements in PM from regional background, urban and industrial sites of Spain, Atmos. Environ., 2007, 41, 7219.

[15] Environmental Protection Agency in Cracow, http://www.Cracow.pios.gov.pl (accessed November 2013).

[16] PN-EN 12341:2006a: Air quality. Determination of the PM10 fraction of suspended particulate matter. Reference method and field test procedure to demonstrate reference equivalence of measurement methods.

[17] PN-EN 14907:2006b: Ambient air quality. Standard gravimetric measurement method for the determination of the PM2.5 mass fraction of suspended particular matter.

[18] Vekemans B., Janssens K., VincZe L., AdAms F., VAn EsPEn P., Analysis of X-ray spectra by iterative least squares (AXIL). New developments, X-Ray Spectry, 1994, 23, 278.

[19] The NOAA Air Resources Laboratory (ARL), http://ready.arl.noaa.gov/HYSPLIT_traj..php (accessed November 2013).

[20] Thurston G.D., SPENGLER J.D., Multivariative assessment of meteorological influences on inhalable particle source impact, J. Clim. Appl. Meteorol., 1985, 24, 1245.

[21] Putaud J.P., Van Dingenen R., Alastuey A., Bauer H., Birmili W., Cyrys J., Flentje H., Fuzzi S., Gehring R., Hansson H.C., Harrison R.M., Hermann H., Hitzenberger R., Huglin C., Jonesa M., Kasper-Giebl A., Kiss G., Kousa A., Kuhlbusch T.A.J., Loschau G., Maenhaut W., Molnar A., 
Moreno T., Pekkanen J., Perrino C., Pitz M., Puxbaum H., Querol X., Rodriguez S., Salma L., Schwarz J., Smolik J., Schneider J., Spindler G., Brink H., Tursic J., Viana M., Wiedensohler A., RAES F., A European aerosol phenomenology. 3. Physical and chemical characteristics of particulate matter from 60 rural, urban, and kerbside sites across Europe, Atmos. Environ., 2010, 44, 1308.

[22] Hansen H.K., Pedersen A.J., Attosen L.M., Villumsen A., Speciation and mobility of cadmium in straw and wood combustion fly ash, Chemosphere, 2001, 45, 123.

[23] Hanoi E., VouTSA D., SAmaRa C., Chemical characterization and source identification/apportionment of fine and coarse particles in Thesaloniki, Greece, Atmos. Environ., 2002, 36, 949. 